\title{
UNIVERSITYOF
}

FORWARD

THINKING

WESTMINSTER用

WestminsterResearch

http://www.westminster.ac.uk/westminsterresearch

Introduction: Geographies of War and Culture Studies

Kelly, D.

This is an Accepted Manuscript of an article published by Taylor \& Francis in Journal of War and Culture Studies, 8 (4) 269-270, 2015.

The definitive version is available online:

https://dx.doi.org/10.1080/17526272.2015.1108582.

The WestminsterResearch online digital archive at the University of Westminster aims to make the research output of the University available to a wider audience. Copyright and Moral Rights remain with the authors and/or copyright owners.

Whilst further distribution of specific materials from within this archive is forbidden, you may freely distribute the URL of WestminsterResearch: ((http://westminsterresearch.wmin.ac.uk/)).

In case of abuse or copyright appearing without permission e-mail repository@westminster.ac.uk 


\section{Introduction: Geographies of War and Culture Studies}

Debra Kelly

\section{University of Westminster}

Although organised chronologically with reference to the war or conflict represented in this collection of six articles, a most striking feature of this varia issue is its geographical spread. We journey from Canada to Australia in the First World War in two opening articles which provide interesting companion pieces on the ambiguities and complexities of recruitment to the armies of the Great War and the effects of its pressures on the lives and experiences of young men at the time: Anna BranachKallas's 'Negotiating Conflicting Narratives of Obligation: conscientious objectors and deserters in Canadian Great War fiction' and Véronique Duché, Diane de Saint Léger and Daniel Russo-Batterham's 'Soldier or Student? The recruitment of Australian university students in the First World War'. From the former British Empire we move to the immediate post-war period in France and the development of further ambiguous attitudes towards the Great War and its enormous losses, this time in Chris Millington's analysis of the relatively less well-known 'Communist Veterans and Paramilitarism in 1920s France: the Association républicaine des anciens combattants'. As the twentieth century develops, the focus of conflict turns to the Middle East, and again two companion articles offer insights respectively into 1956 Gaza and the Khan Younis massacre (represented in a 2009 graphic narrative) and post-civil war Lebanon (represented in a 2007 documentary performance) with Jeanne-Marie Viljoen's “'Productive Myopia”: seeing past history's spectacle of accuracy in Joe Sacco's Footnotes in Gaza', and Solveig Gade's 'Learning to Live with Ghosts in the Aftermath of War: on documentary strategies in Rabih Mroué's How Nancy Wished That Everything was an April Fool's Joke'. These two articles provide both a contextualisation of those conflicts and a close reading of the more contemporary cultural representations which they have inspired. Finally, we journey to Denmark as the issue closes with a different form of contemporary cultural representation of conflict, this time the invention of commemorative practice with reference to recent conflict in Afghanistan, in Tea Dahl Christensen's 'The Figure of the Soldier: discourses of indisputability and heroism in new Danish commemorative practice', in which three salient discourses - of the soldier as hero, as a figure fighting in ethical warfare and (again) as a veteran are analysed.

We journey also through a geography of analytical and theoretical approaches to war and culture studies, from the close textual analysis of fiction (Branach-Kallas), the discourse analysis of public speeches and political discourse (Dahl Christensen), to close visual / performance analysis (Gade) and further textual and visual analysis informed by philosophical theorising on the nature of violence (Viljoen), to in-depth archival work (Duché, de Saint Léger and Russo-Batterham; and Millington). This issue, in its geographical, temporal and disciplinary diversity, underlines the necessity of facing the many forms of representation of the complexities and of the 
troublesome and disruptive aspects of war and of its memories. In so doing, it bears fitting witness to the openness of mind and of ambition of the original Group for War and Culture Studies as 2015, the year of the twentieth anniversary of its founding, draws to a close. 